\title{
APRESENTAÇÃO
}

\author{
PRESENTATION
}

\section{DOSSIÊ ESPECIAL 50 ANOS DA PEDAGOGIA DO OPRIMIDO}

A insubmissão é a energia que impulsiona os movimentos que transformam modos sociais de opressão ou coerção. Tais movimentos se constituem como significativos atores políticos a disputar em cenários e campos de profundas contradições, com forças hegemônicas e dominantes poderosas e bem articuladas, Direitos, espaços nas políticas de Estado e a própria hegemonia sobre o projeto de sociedade que se deva encaminhar. Em meio a esses movimentos, os sujeitos singulares são perpassados por um verdadeiro processo político-educativo. Pois, o próprio movimento é também um agente educador.

Neste sentido, falando de uma educação que se dá na disputa por projetos de sociedade que se contraponham a modos vigentes de opressão e coerção e que tem seus sujeitos constituídos enquanto educadores-educandos, é que emerge a importância da pedagogia de Paulo Freire. E, este ano de 2018 é, particularmente, importante para a reflexão que se pretende enriquecer por tal pedagogia, pois, comemora-se o cinquentenário da obra "Pedagogia do Oprimido". Sob este marco é que o Centro Paulo Freire - Estudos e Pesquisas realizou, em setembro último, seu X Colóquio Internacional Paulo Freire, com o tema "50 anos da Pedagogia do Oprimido: Opressão e Libertação na Atualidade”.

Os colóquios internacionais do Centro Paulo Freire vêm se constituindo como uma experiência de intercâmbio e diálogo entre pessoas estudiosas do pensamento freireano e praticantes de sua pedagogia, provenientes de várias partes do Brasil e do mundo, apresentando resultados e processos de estudos e pesquisas com referencial na pedagogia de Paulo Freire, possibilitando a construção de novos saberes e socializando novas práticas. 


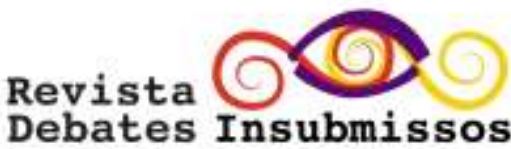

Neste contexto, é que destacamos, dentre as comunicações apresentadas no X Colóquio Internacional Paulo Freire, os dez trabalhos aqui publicados, contemplando educadoras e educadores de diversas regiões do país, dentre as temáticas tratadas no colóquio. Registramos, contudo, que selecionar dez trabalhos do universo de mais de 160 comunicações apresentadas. Não foi tarefa fácil. Por isso, salientamos, também, que o fato de não se estar aqui contemplada não desmerece uma comunicação. Contudo, alguns critérios tiveram que ser elencados a fim de obedecer a exigências editorias determinadas pelas instâncias de avaliação nacional de periódicos, tais como, a presença de um professor doutor como um dos autores, o limite de autores por trabalho e a diversidade e inovação de temas e regiões representadas. Além da nossa seleção, os artigos aqui publicados ainda passaram pelo sistema de avaliação da Revista, no qual inclui duplas de Avaliadores Ad Hoc para cada arquivo, para finalmente serem aprovados.

Assim, apresentamos agora um breve panorama do conjunto dos trabalhos selecionados.

Discutindo as contribuições do "círculo de cultura" para as práticas de ensino, pesquisa e extensão nas universidades e escolas públicas, pelo qual se pode valorizar uma dinâmica recíproca entre conhecimentos e experiência, temos Rosária Helena Ruiz Nakashima, Karolina Martins Almeida e Matheus Pereira Silva, com o texto "'Círculo de Cultura' Freireano: espaço dialógico de ensino, pesquisa e extensão".

Abordando o processo de formação humana inerente à pedagogia do Movimento dos Trabalhadores Sem Terra (MST), que se caracteriza pela incorporação da categoria "Ser Mais", sistematizada por Freire, temos o trabalho de Maria Fernanda dos Santos Alencar e Allan Diêgo Rodrigues Figueiredo, com o título "Paulo Freire e a Pedagogia do MST: caminhos para (re)pensar a formação humana".

Pautando-se por Freire, Moisés Pereira Silva e Jôyara Maria Silva de Oliveira apresentam experiência de pesquisa-ação realizada em sala de aula que teve como objetivo verificar o potencial pedagógico da narrativa acerca da história dos sujeitos, com o texto "Paulo Freire e a Educação Histórica: desafios e possibilidades para a atuação docente no sistema modular de ensino da rede pública estadual paraense". 


\section{Debates Insubmissos}

Revista

Analisando a construção do currículo do curso de aperfeiçoamento de Educação Popular em Saúde, promovido pela SGEP/MS, coordenado pela EPSJV/FIOCRUZ, que, fundamentado nas ideias de Freire, incorpora categorias como diálogo, problematização, amorosidade, construção compartilhada do conhecimento, participação democrática e popular, apresentamos o texto "Reflexões sobre um Currículo Argiloso e o Potencial da Educação Popular na Formação de Trabalhadores e Movimentos Sociais em Defesa do SUS”, de Grasiele Nespoli, Vera Joana Bornstein e Irene Goldschmidt.

Tratando da problemática ético-política dos refugiados, destacando a atualidade da Pedagogia do Oprimido, o trabalho de Valdir Borges, Luiz Alberto de Alcantara e Gabriela Ribeiro Campos, assinala a crise migratória no contexto de uma crise humanitária, com o trabalho intitulado "A Indifrença da Humanidade para com os Refugiados Da Terra: uma problemática ético-política da atualidade".

Apresentando a influência de Freire na Sociopoética, entendida como procedimento de investigação contra-hegemônico, o qual tem por objetivo provocar a transformação na leitura de mundo por parte dos sujeitos, implicando a mudança nas ações, a favor da interferência crítica na sociedade, temos o texto "Inspirações Freireanas para o Método Contra-hegemônico da Sociopoética”, de Eugênia de Paula Cordeiro, Ana Márcia Monteiro e Monaliza Holanda dos Santos.

Por sua vez, o trabalho "A Problematização do Programa "Escravo, Nem Pensar" na Perspectiva Freiriana”, de Hildete Pereira dos Anjos, Moisés Pereira Silva e Jôyara Maria Silva de Oliveira, analisa o material didático do programa "Escravo, nem pensar", da ONG Repórter Brasil, que atua nas escolas públicas da região prevenindo o trabalho escravo contemporâneo por meio de uma educação emancipadora e dialógica.

Apresenta-se de Deysiene Cruz e Patrícia Carla da Hora, o texto "A Intergeração na Educação de Jovens e Adultos - EJA como possibilidade de Prevenção dos maus Tratos Intrafamiliar contra Pessoa Idosa”. Este aborda a temática intergeracional no contexto da Educação de Jovens e Adultos destacando a categoria de "maus tratos", apontando o espaço de 
formação da EJA como experiência de interlocução e integração entre jovens, adultos e idosos, procurando promover saberes e ações que previnam ações de maus tratos contra idosos.

Temos ainda, o texto "As Bases Freireanas da Educomunicação Presentes no Programa Conexões Periféricas", de Maria Eleni Henrique da Silva e Isabel Mayara Gomes Fernandes Brasil. Este discorre acerca da prática educomunicativa do Programa Conexões Periféricas da Rede Cuca da Prefeitura de Fortaleza, cuja efetividade possibilitou a releitura de categorias fundamentais da pedagogia de Freire, tais como co-laboração, tema-gerador/ pergunta e tolerância, que constituem a educação enquanto ação política,

Por fim, no texto "Entre Martinho Lutero e Paulo Freire: pedagogias pertinentes", Everaldo Fernandes da Silva e William Francisco da Silva analisam as aproximações e distanciamentos entre as pedagogias Luterana e Freireana, salientando que, a despeito do distanciamento espaço-temporal, ambas as pedagogias coincidem por se constituírem enquanto processo educativo-políticas.

Acreditamos que a leitura destes textos contribuirá para a provocação de reflexões cada vez mais crítica sobre aquela que é a problemática que anima a todas e todos envolvidos com práticas emancipatórias, a saber: a complexa e plural realidade dos processos de educação libertadora.

Boa leitura!

André Gustavo Ferreira da Silva Presidente do Centro Paulo Freire - Estudos e Pesquisas 